\title{
Manpower Policy in Finland
}

\author{
By TIMO FILPUS \\ Ministry of Labor
}

Great instability has been and is a distinct characteristic of the Finnish labor market. Significant quantitative and structural imbalance prevails between the demand for and the supply of labor. The near future also appears very bleak at least when viewed from the bottom of this economic depression. The ideal aim of manpower policy, full employment, is postponed further and further as the years go by.

Many employment problems familiar to Western European countries are acute here in Finland. Although the average rate of growth in production has been faster than in the OECD-countries on the average, the total demand for labor, i.e. the number of jobs, has not grown rapidly enough. The number of new jobs in the processing and service industries has indeed risen, but not fast enough in order to sufficiently compensate for the jobs which have been eliminated in agriculture and forestry. In addition, the growth of the workingage population has been unusually vigorous because of the post-war large age groups. The number of jobs in relation to the supply of labor has been and is too small, except for the boom of $1974-75$.

The cyclical and seasonal fluctuations in the labor force originating in the demand sector are exceptionally large in Finland. These fluctuations are great because of the large proportion of foreign trade on one hand and the northern location of Finland on the other. Regional differences in employment are also great. For many years southern Finland has enjoyed full employment. The unemployment rate in the northern and eastern areas of Finland, however, has remained around $5-10 \%$.

Within the last 15 years a broad transition has taken place in the industrial structure of the labor force - in a very short time indeed. The proportion of manpower in agriculture and forestry was $36 \%$ in 1960 . It is now $13 \%$. The proportion in the service industries was $32 \%$ in 1960 . It is now $50 \%$. The structural change has been necessary, but its rapidity has caused unwanted instability in the labor market.

The difficulties lying in the supply sector of the labor force have arisen mainly from the fact that the growth of the labor force has been rapid and the adaptability of the labor force has been slower than the structural changes would have required. Vocational training is inadequate in the oldest age groups and also partly in the large age groups. A serious threat to the healthy age structure of labor is emigration. Sweden's high standard of living and good employment have attracted tens of thousands of young Finnish workers. The migration loss of 1977 may rise to 15000 persons. 
The extensive emigration of young and trained labor signifies a notable loss to the Finnish national economy and a gain for Sweden. The net renewal rate of the Finnish population has dropped to the $85 \%$-level. When the threat of continuous emigration is added to this renewal rate, a population policy crisis can be seen in the offing.

\section{Employment in the year 1977}

Now that the growth of production has been at a standstill for three years, the demand for labor has dropped and unemployment has risen to a recordbraking level. While Finland's unemployment rate remained around $2 \%$ in "good times", it is now in 1977 almost $6 \%$ (130000 persons). It is believed that the economic recovery program drawn up by the Finnish government in the summer of 1977 will gradually mend the situation.

In the long run it is estimated that Finland's potential to gain equilibrium in her national economy and employment is good. We have abundant renewable natural resources and manpower, in addition to which our exports have wideranging markets in both Western Europe and the SEV-countries.

\section{Manpower policy}

Finnish manpower policy has been maintained in the spirit of the so-called active manpower policy of the OECD. The aim has been full employment which would support economic growth. In the "good times" of the 1960 s and the 1970 s we became accustomed to having employment cared for in a more-or-less satisfactory manner. During this long-lasting depression various matters and their interrelations must be re-evaluated.

In the manpower policy program drawn up at the Ministry of Labor, the duties of the Administration of Labor have been defined as the following:

- promote and support those economic policy measures which affect the demand for labor, with the purpose of reaching and maintaining a high and stabile employment rate;

- use all available means to support and implement those measures which contribute to the adjustment of the demand for and the supply of labor;

- create as many options as possible for the individual in the labor market and create new ways to enter working life, and

- look after and safeguared the livelihood of the unemployed.

Within the limits of these principles of action the Administration of Labor is responsible for the three following sectors:

1. development and guidance of labor resources,

2. counteracting disturbances on employment through measures affecting the demand for labor, and

3. safeguarding the livelihood of the unemployed. 
The Finnish Administration of Labor has at its disposal most of the methods of modern manpower policy: employment service, vocational guidance, selective means for looking after employment etc. In the last few years the development of employment training courses has been especially vigorous.

The long-lasting economic depression and unemployment, which has risen to new heights, prove, however, that neither our national economy nor our manpower policy has the sufficient readiness and the resources for that which is most important, the maintenance of employment. In both the OECD and in joint acitivities among the Nordic countries, in both of which Finland participates, a new »employment policy strategy of slow economic growth» has been under development. The aim of this new strategy is to see that in the economic policy sector and in all other social development policy sectors the improvement of employment is made the prime goal. Experiences thus far have shown that various old and new methods and their combinations are not enough. Achieving at least a satisfactory level of employment requires a quicker pace in the growth rate of production.

\section{Manpower policy - other social development policy}

The various sectors of social development policy: economic, manpower, educational, regional, housing, population policy etc. have been traditionally relatively independent in Finland, operating without strong centralized control. In the last few years an attempt has been made to improve the coordination of the various sectors in order to achieve balanced employment, among other things. The most important means of coordination at the moment is the Government's economic budget and action plan. This is drawn up each year and covers the five subsequent years. Essential to manpower policy is the reform of the entire educational system surrently underway. Another important undertaking is the planning of development in each province. Goals concerning jobs and population have been drawn up in Finland for each province. With the aid of planning for each province, the attempt is being made to coordinate activities in the different social development policy sectors in order to realize the afore-mentioned goals.

\section{Population policy}

Perhaps the worst manpower policy problem in the development of the population was caused by the large age groups born after the war. Part of the large age groups did not receive vocational training and were not able to find work in Finland. Another factor detrimental to the ability of manpower policy to function has been the extensive internal migration connected to the rapid 
transition in the industrial structure. This internal migration is still going on. Rapidly expanding population and job centers characterized by many problems sprang up. At the same time other areas began to become deserted and gained serious unemployment problems.

A special characteristic of Finland is that the participation of women in the labor force has been one of the highest in the world. This factor has many connections with the maintenance of manpower policy. Perhaps the most central problem at the moment is how to guarantee the renewal of the population and, at the same time, the employment of women.

The most timely population and manpower question now is emigration. Not only does it exert pressure on our national economy, but, if it continues, it will signify quite a sharp drop in the size of the labor force in the $1980 \mathrm{~s}$. Will we be able to develop a social development policy with which we can prevent the kind of development currently underway?.

\title{
The Effects of Population Factors on Educational Planning
}

\author{
By ILPO KOKKO \\ Ministry of Education
}

Population factors and population policy goals form an important basis of educational planning. Endeavors to arrange the supply of educational services are being made according to generally accepted aims, so that citizens will have an equal opportunity to use educational services, regardless of means or place of residence, among other things. In accordance with this aim an attempt at equalizing the regional supply of educational services is being made, so that post-compulsory education would be available equally all over the country, corresponding to the average age group of schooling age.

Because educational policy is in many cases considered a means of achieving certain economical and regional policy goals and concurrently also certain population goals, in the past few years the active focus of educational planning has begun to be centered on directing vocational training and university level education so that it would support regional, economical and population development. In the following we will take a brief look at the effects of the goals mentioned here on today's educational planning.

\section{The effect of population development on the compulsory school}

The pupil admission need of the compulsory comprehensive school is affected mainly, by the number of children of compulsory school age and their regional 